\title{
Efektivitas Promosi Starbucks Greener Day Melalui Instagram terhadap Minat Beli Konsumen di Jakarta
}

\author{
Clara Vincy Tansia, Diah Ayu Candraningrum \\ clara.915170171@stu.untar.ac.id,diahc@fikom.untar.ac.id
}

Fakultas Ilmu Komunikasi Universitas Tarumanagara

\begin{abstract}
Drinking coffee has become lifestyle of Indonesian people. Coffee is one of the staples most often consumed by Indonesian people. The company that has the largest coffee sales in Indonesia is Starbucks. This research raised the discussion about one of Starbucks promotions, Greener Day. In this there are 2 variables, namely promotion and buying interest variables. In this research writer uses quantitative research collect data with form of survey and using Starbucks in Jakarta as observation unit. Primary data collected by simple random sampling method, and collected by 100 respondents related to Starbucks Greener day promotion. Data analysis using SPSS version 22.0. Based on the results of the research conducted there is a fairly strong level of effectiveness between Starbucks Greener Day Promotion on Instagram to consumer buying interest in Jakarta, because it is at intervals of 0.61-0.80 on the Coefficient of Correlation test results. Through the results of the Partial Influence Significance test (T Test) also showed a significant influence between the Variable Promotion $(X)$ and Buy Interest $(Y)$.
\end{abstract}

Keywords: buying interest, promotion, starbucks

\begin{abstract}
Abstrak
Minum kopi sudah menjadi gaya hidup masyarakat Indonesia. Kopi merupakan salah satu bahan pokok yang paling sering dikonsumsi oleh masyarakat Indonesia. Perusahaan yang memiliki penjualan kopi terbesar di Indonesia adalah Starbucks. Penelitian ini mengangkat pembahasan mengenai salah satu promosi Starbucks yaitu Greener Day. Didalam ini terdapat 2 variabel, yaitu variabel promosi dan minat beli. Penelitian ini menggunakan pendekatan kuantitatif dengan metode pengumpulan data berupa survei, dan menggunakan Starbucks di Jakarta sebagai unit observasi. Data primer yang dikumpulkan dengan metode simple random sampling, dan terkumpul sebanyak 100 responden yang berkaitan dengan promosi Starbucks Greener day. Analisis data menggunakan SPSS versi 22.0. Berdasarkan hasil penelitian yang dilakukan terdapat tingkat efektivitas yang cukup kuat antara Promosi Starbucks Greener day di Instagram terhadap minat beli konsumen di Jakarta, karena berada di interval sebesar 0,610,80 pada hasil uji Koefisien Korelasi. Melalui hasil uji Signifikansi Pengaruh Parsial (Uji T) juga menunjukan adanya pengaruh yang signifikan antara variabel Promosi (X) dan Minat Beli (Y).
\end{abstract}

Kata Kunci: minat beli, promosi, starbucks

\section{Pendahuluan}

Starbucks adalah salah satu perusahaan terbesar di industri kopi di Indonesia Starbucks adalah perusahaan waralabayang didedikasikan untuk menjual kopi dan menggunakan konsep tempat ketiga untuk konsumen. Instagram adalah salah satu media sosial yang digunakan Starbucks sebagai media promosi. Menurut Bambang, Instagram merupakan aplikasi dari smartphone yang didedikasikan untuk media 
sosial. Salah satu media sosial yang fungsinya hampir sama adalah Twitter, namun perbedaannya terletak pada pengambilan gambar dan lokasi untuk membagikan informasi dengan penggunaan. Instagram juga dapat memberikan inspirasi, kreativitas, dan motivasi kepada penggunanya Atmoko (2012).

Starbucks juga merupakan perusahaan yang peduli dengan lingkungan sekitarnya. Promosi yang dilakukan Starbucks banyak merubah perspektif bisnis. Salah satu promosi yang dilakukan Starbucks adalah Greener day. Promosi Greener day menawarkan kepada konsumen untuk membeli tumblr dalam rangka mengurangi sampah plastik dan konsumen juga mendapatkan potongan harga dalam membeli minuman dengan menggunakan tumblr. Menurut Kotler dan Keller (2012), Bauran Pemasaran mencakup lima (5) alat promosi.

Promosi ini tentu banyak menarik konsumen untuk membeli. Melalui sosial media Instagram. Starbucks Indonesia mempromosikan dan menginformasikan kepada konsumen tentang produk yang dijual dan nilai yang akan didapatkan konsumen melalui pembelian dari produk yang ditawarkan oleh Starbucks.

Sesuai dengan pernyataan di atas penulis akan mengambil populasi konsumen yang berada di Jakarta, alasan penulis memilih konsumen yang berada di Jakarta karena Jakarta merupakan salah satu kota di Indonesia dengan pendapatan perkapita tertinggi sesuai dengan target market dari Starbucks yang menetapkan bahwa target konsumen Starbucks adalah konsumen di level menengah ke atas, selain kopi Starbucks juga menawarkan tempat berdiskusi yang nyaman untuk konsumennya.

Bentuk promosi Starbucks Greener day mengajak konsumen untuk menggunakan tumblr dibandingkan gelas plastik. Sisi positif dari penggunaan tumblr adalah mengurangi sampah plastik. Jika konsumen membeli Starbucks pada saat promosi Greener day, konsumen juga akan mendapatkan potongan harga 50\% dari harga normal. Hal ini tentu akan menarik konsumen untuk membeli produk yang disediakan oleh Starbucks.

Berdasarkan fenomena dan permasalah yang dijelaskan di atas penulis ingin meneliti apakah Promosi Starbucks Greener day melalui Instagram efektif dalam meningkatkan minat beli konsumen di Jakarta?

\section{Metode Penelitian}

Pendekatan yang digunakan pada penelitian ini adalah pendekatan kuantitatif yang digambarkan dengan tingkat efektivitas promosi Starbucks Greener day melalui Instagram terhadap minat beli konsumen di Jakarta. Alat pengumpulan data dalam penelitian ini adalah kuesioner. Kuesioner merupakan alat pengumpulan data utama dengan menggunakan metode survei untuk memperoleh pendapat dari responden (Atmaja dan Wijaya, 2019). Yang kedua studi pustaka, Menurut Nazir (2013), studi pustaka merupakan teknik pengumpulan data yang melibatkan penelitian dalam buku, dokumen, catatan, dan laporan yang berkaitan dengan masalah yang akan dipecahkan. Dan yang ketiga yaitu wawancara. Menurut Stewart dan Cash, wawancara adalah interaksi yang dimana terjadinya pertukaran informasi, tanggung jawab, tanggung jawab, perasaan, keyakinan, serta motivasi. Tujuan dilakukannya wawancara dalam penelitian kuantitatif ini adalah untuk menggali data yang dibutuhkan peneliti dan untuk melengkapi serta memperkuat data (Herdiansyah,2010).

Penyebaran kuesioner dilakukan dengan simple random sampling kepada 100 responden yang mengetahui promosi Starbucks Greener day melalui Instagram. dan adanya 2 variabel yang diambil dalam penelitian ini, yaitu: 
Clara Vincy Tansia, Diah Ayu Candraningrum: Efektivitas Promosi Starbucks Greener Day Melalui Instagram terhadap Minat Beli Konsumen di Jakarta

a. Promosi sebagai variabel (X) menggunakan teori dari bauran promosi yang dikutip dari Kotler dan Keller (2012) yang terdapat atas 5 (lima) alat-alat promosi, yaitu:

- Advertising (periklanan), yaitu segala bentuk presentasi dan promosi nonpribadi yang dibayarkan melalui sponsor untuk menampilkan ide, barang atau jasa.

- Sales promotion (promosi penjualan), yaitu insentif jangka pendek yang mendorong pembelian atau penjualan suatu produk dan layanan

- Personal Selling (penjualan perseorangan), yaitu presentasi pribadi oleh tenaga penjualan yang tujuannya adalah mempromosikan penjualan dan membangun hubungan dengan konsumen.

- Public relations (hubungan masyarakat), yaitu menjalin hubungan yang baik dengan konsumen untuk memperoleh publisitas yang baik, membentuk citra perusahaan yang baik, dan menangani atau mengkoreksi rumor, cerita, dan peristiwa yang tidak menguntungkan pihak perusahaan.

- Direct Marketing (penjualan langsung), yaitu hubungan langsung dengan sasaran konsumen yang bertujuan untuk memperoleh tanggapan segera dan mendorong hubungan yang baik dan panjang dengan konsumen.

b. Minat beli sebagai variabel (Y) yang mencakup 4 indikator menurut Ferdinand (Hidayat et al., Elita, dan Setiaman, 2012) yaitu:

- Minat transaksional, yaitu kecenderungan individu untuk membeli produk. Yang dapat diartikan bahwa konsumen tertarik untuk membeli produk yang diinginkan

- Minat referensial, yaitu kecenderungan individu untuk merekomendasikan produk yang mereka gemari kepada orang lain. Yang artinya konsumen sudah berminat membeli dan akan menyarankan kepada kerabat terdekatnya untuk membeli produk yang sama

- Minat preferensial, yaitu minat individu yang memiliki prefrensi utama terhadap produk yang diinginkan.

- Minat eksploratif, menggambarkan perilaku individu yang selalu mencari informasi tentang produk yang diminati dan mencari informasi untuk mendukung karakteristik positif dari produk yang diminati oleh konsumen.

\section{Hasil Temuan dan Diskusi}

Hasil dari penelitian ini dapat didapatkan melalui hasil kuesioner yang mencakup 10 pernyataan dari variabel $\mathrm{X}$ (Promosi) dan 8 pernyataan dari variabel $\mathrm{Y}$ (Minat beli) dengan total 18 pernyataan dari kuesioner. Penulis memperoleh 100 responden melalui penyebaran kuesioner dengan menggunakan media Google Form. Setelah penulis mendapatkan 100 responden penulis mengolah data menggunakan SPSS (Statistikal Package for the Sosial Science) Version 22.0 untuk menguji hasil penelitian. Tingkat validitas menurut Morrisan, pengukuran pada populasi memerlukan alat ukur yang valid (Aprianto dan Candraningrum, 2020).

Hal ini dikarenakan validitas mengacu pada seberapa jauh suatu ukuran empiris cukup menggambarkan arti sesungguhnya dari konsep yang sedang diteliti. Dapat disimpulkan bahwa dari setiap butir pernyataan dari seluruh variabel penelitian ini dinyatakan valid dan pengujian pada uji reliabilitas yang dinilai menggunakan 
Cronbach's Alpha dihitung jika nilai di bawah 0,6 maka dapat dinyatakan bahwa alat ukur tersebut memiliki nilai reliabilitas yang rendah, menurut Siregar (2013) reliabilitas dianggap cukup apabila Cronbach's Alpha dihitung lebih besar dari 0,6 jika nilai Cronbach's Alpha dibawah 0,6 maka dapat ditarik kesimpulan bahwa alat ukur tersebut memiliki reliabilitas yang rendah. .

Pada hasil penelitian ini dinyakatan bahwa variabel X (promosi) dan variabel Y (minat beli) dinyatakan reliabel karena angka memiliki angka Cronbach's Alpha sebesar 0,903 pada variabel X (promosi) dan 0,930 pada variabel Y (minat beli). Selanjutnya data diuji tingkat normalitas yang menghasilkan sebesar 0,200. Hal ini menunjukan bahwa nilai berada diatas 0,05 yang diartikan bahwa data berdistribusi normal.

Tabel 1. Uji Regresi Sederhana dan Uji $T$ Coefficient $^{2}$

\begin{tabular}{|c|c|c|c|c|c|c|}
\hline \multirow{2}{*}{\multicolumn{2}{|c|}{ Model }} & \multicolumn{2}{|c|}{$\begin{array}{l}\text { Unstandardized } \\
\text { Coefficients }\end{array}$} & \multirow{2}{*}{$\begin{array}{c}\text { Standardized } \\
\text { Coefficients } \\
\text { Beta }\end{array}$} & \multirow[b]{2}{*}{$\mathrm{t}$} & \multirow[b]{2}{*}{ Sig. } \\
\hline & & B & Std. Error & & & \\
\hline \multirow[t]{2}{*}{1} & (Constant) & 2,364 & 2,488 & & ,950 &, 344 \\
\hline & TOTAL_X & ,687 & ,061 & ,751 & 11,253 & ,000 \\
\hline
\end{tabular}

Sumber: Olahan Data Peneliti

Menurut Siregar (2013) aturan pengujian berdasarkan nilai signifikasi hasil SPSS antara lain:

a. Jika nilai Sig. $<0,05$ maka variabel bebas berpengaruh signifikan terhadap variabel terikat.

b. Jika nilai Sig. $>0,05$ maka variabel bebas tidak berpengaruh signifikan terhadap variabel terikat.

Hasil dari uji regresi sederhana dan uji T menunjukkan nilai koefisien regresi promosi sebesar 0.687 dengan signifikansi 0.000 dapat diartikan sig (p) $<0,05$, yang menunjukkan koefisien regresi sederhana berpengaruh signifikan terhadap minat beli konsumen di Jakarta.

Tabel 2. Hasil Koefisien Korelasi

Hasil Uji $\mathbf{R}^{2}$

\begin{tabular}{|c|c|c|c|c|}
\hline Model & $\mathrm{R}$ & R Square & Adjusted R Square & $\begin{array}{l}\text { Std. Error of the } \\
\text { Estimate }\end{array}$ \\
\hline 1 &, $751^{\mathrm{a}}$ &, 564 & ,559 & 4,888 \\
\hline
\end{tabular}

Sumber: Olahan Data Peneliti

Hasil dari Koefisien Korelasi bahwa nilai (R) adalah sebesar 0.751 yang dapat diartikan bahwa hubungan $\mathrm{X}$ dan $\mathrm{Y}$ dikatakan cukup erat karena berada dalam interval 0,61-0,80. Berdasarkan tabel diatas dapat disimpulkan bahwa hasil koefisien determinasi dengan menggunakan $\mathrm{R}$ square $\left(\mathrm{R}^{2}\right)$ yaitu sebesar 0,564. Menurut Siregar 
Clara Vincy Tansia, Diah Ayu Candraningrum: Efektivitas Promosi Starbucks Greener Day Melalui Instagram terhadap Minat Beli Konsumen di Jakarta

(2013), koefisien determinasi adalah angka yang digunakan untuk menggambarkan dan mengetahui kontribusi atau sumbangan yang diberikan oleh sebuah variabel atau lebih X (bebas) terhadap variabel Y (terikat). Dengan nilai tersebut maka dapat disimpulkan bahwa kemampuan variabel X promosi Starbucks Greener day di Instagram dalam memberikan kontribusi terhadap variabel Y minat beli konsumen di Jakarta adalah sebesar 56,4\%. Adapun sisa 43,6\% dijelaskan oleh berbagai faktor yang tidak diteliti dalam penelitian ini.

\section{Simpulan}

Berdasarkan hasil dari penelitian ini maka penulis mengambil kesimpulan sebagai berikut promosi Starbucks Greener day melalui Instagram terhadap minat beli konsumen di Jakarta memiliki hubungan yang positif karena promosi Starbucks Greener day memiliki pengaruh yang signifikan terhadap minat beli konsumen di Jakarta sebesar 56,4\% yang dapat dibuktikan melalui hasil uji koefisien determinasi. Promosi Starbucks Greener day melalui Instagram memiliki hubungan yang signifikan terhadap Minat beli konsumen di Jakarta. Artinya efektivitas Promosi Starbucks Greener day melalui Instagram terhadap Minat beli konsumen di Jakarta dan terdapat nilai Sig $<\alpha$ yaitu $0,000<0.00$, yang dapat diartikan bahwa Promosi Starbucks Greener day melalui Instagram memiliki hubungan yang signifikan terhadap Minat beli konsumen di Jakarta.

Promosi Starbucks Greener day melalui Instagram memiliki kontribusi yang besar dalam meningkatkan minat beli konsumen karena promosi ini bertujuan untuk mengurangi sampah plastik. Manfaat dari temuan dalam penelitian ini memberikan dampak yang positif dalam membuat suatu promosi Starbucks salah satu promosi yang positif adalah Greener day. Dan tetap mempertahankan promosi Starbucks untuk menciptakan lingkungan kehidupan yang lebih baik.

\section{Ucapan Terima Kasih}

Pada kesempatan ini penulis mengucapkan terima kasih dan bersyukur kepada Tuhan yang Maha Esa karena berkah-Nya penulis dapat menyelesaikan jurnal skripsi ini. Oleh karena itu pada kesempatan ini penulis ingin mengucapkan terima kasih kepada Ibu Diah Ayu Candraningrum S.T., M.B.A., M.Si. selaku Dosen pembimbing yang telah meluangkan waktunya untuk membimbing.

\section{Daftar Pustaka}

Aprianto, N \& Candraningrum, D. A. (2020). Pengaruh Personal Selling terhadap Minat Beli Produk PRUlink Generasi Baru Nasabah Prudential Life Assurance Indonesia. Jurnal Komunikasi Untar Prologia. Vol. 3, No. 2, Hal 313-319. <https://journal.untar.ac.id/> Diunduh tanggal 25 September 2020.

Atmaja, K. J., \& Wijaya, I. N. S. W. (2019). Pengembangan Sistem Evaluasi Kinerja Dosen (E-Kuesioner) Stmik Stikom Indonesia. JST (Jurnal Sains dan Teknologi), Vol. 8, No. 1, Hal 55-64.

Atmoko, B. D. (2012). Instagram Handbook Tips Fotografi Ponsel. Jakarta: Media Kita.

Herdiansyah, Haris. (2010). Metode Penelitian Kualitatif untuk Ilmu-ilmu Sosial. Jakarta: Salemba Humanika. 
Hidayat, Elita \& Setiaman. (2012). Hubungan Antara Atribut Produk Dengan Minat Beli Konsumen. Universitas Padjajaran. Vol 1. No 1.

Kotler, P \& Keller, K. L. (2012). Marketing Management, Edisi 13 Jilid 1. Erlangga Nazir, M. (2013). Metode Penelitian. Bogor: Penerbit Ghalia Indonesia.

Siregar, S. (2013). Metode Penelitian Kuantitatif. Jakarta: PT Fajar Interpratama Mandiri. 